\title{
Human toenails as a biomarker of exposure to elevated environmental arsenic
}

\author{
Mark Button $^{\mathrm{a}, \mathrm{b}}{ }^{*}$, Gawen R. T. Jenkin ${ }^{\mathrm{b}}$, Chris F. Harrington ${ }^{\mathrm{c}}$ and Michael J. Watts ${ }^{\mathrm{a}}$
}

\author{
5 Received (in $X X X, X X X) X$ th $X X X X X X X X X 200 X$, Accepted $X$ th $X X X X X X X X X 200 X$ \\ First published on the web $X$ th $X X X X X X X X X 200 X$ \\ DOI: 10.1039/b000000x
}

A pilot study was conducted to determine the applicability of toenails as a biomarker of exposure to elevated environmental arsenic (As) levels. A total of 17 individuals were recruited for the pilot 10 study: 8 residents living near to a former As mine, Devon, UK, forming the exposed group, plus 9 residents from Nottinghamshire, UK, with no anticipated As exposure who were used for comparison as a control group. All toenail samples were thoroughly washed prior to analysis and the wash solutions retained for As determination via ICP-MS to provide an indication of the background environmental As levels for each group. Total As was determined in washed toenail 15 samples via ICP-MS following microwave assisted acid digestion. Concentrations of total As in the toenails of the exposed group were elevated, ranging from 858 to $25,981 \mu \mathrm{g} \mathrm{kg}^{-1}$ (geometric mean $=5406 \mu \mathrm{g} \mathrm{kg}^{-1}$ ), compared to the control group whose toenail As concentrations ranged from 73 to $273 \mu \mathrm{g} \mathrm{kg}^{-1}$ (geometric mean $=122 \mu \mathrm{g} \mathrm{kg}^{-1}$ ). Higher levels of exogenous As contamination were present on the toenails of the exposed group (geometric mean $=506 \mu \mathrm{g} \mathrm{kg}^{-1}$ ) compared to the 20 control group (geometric mean $=4.0 \mu \mathrm{g} \mathrm{kg}^{-1}$ ) providing evidence of higher environmental As levels in the exposed group. Total As concentrations in toenail samples were positively correlated to environmental As levels $(\mathrm{r}=0.60, \mathrm{p}<0.001)$. HPLC-ICP-MS analysis of aqueous toenail extracts revealed inorganic arsenite $\left(A s^{\mathrm{III}}\right)$ to be the dominant species extracted $(\sim 83 \%)$ with lesser amounts of inorganic arsenate $\left(\mathrm{As}^{\mathrm{V}}\right)$ and organic dimethylarsinate $\left(\mathrm{DMA}^{\mathrm{V}}\right)$ at $\sim 13 \%$ and $\sim$ ${ }_{25} 8.5 \%$ respectively. Arsenic speciation in analysed toenail extracts from the two groups was comparable. The only notable difference between groups was the presence of small amounts $(<1$ $\%)$ of organic methylarsonate $\left(\mathrm{MA}^{\mathrm{V}}\right)$ in two toenail samples from the exposed group. Toenails are presented as a viable biomarker of exposure at sites with elevated environmental As, such as the former mining sites found throughout Devon and Cornwall, UK.

\section{${ }_{30}$ Introduction}

Arsenic is naturally occurring and ubiquitous in the environment. Humans are exposed to As via contaminated water, food, soil and dust ${ }^{1}$. Chronic exposure to As is associated with increases in lung, liver, bladder and kidney 35 cancer, skin keratoses and peripheral vascular disease ${ }^{2,3}$. Biological markers (biomarkers) can be utilised to make quantitative estimates of exposure to harmful substances ${ }^{4}$ and subsequent risk of disease. There is now increasing interest in the use of human nails as a routine biomarker of As exposure.

${ }_{40}$ On ingestion, soluble arsenic is adsorbed from the gastrointestinal tract and distributed to all bodily systems in the blood, accumulating in many body parts, in particular the keratin rich materials such as hair and nails ${ }^{5}$. Arsenic is thought to accumulate in hair and nails as a result of its ${ }^{45}$ affinity for sulphydryl groups ${ }^{6}$ and remains isolated from the body's metabolic processes both after nail formation and throughout nail growth ${ }^{7}$. The long-term accumulation of As in human nails makes them more useful as a biomarker of chronic As exposure than blood or urine in which the 50 residence time of As is at most a few days ${ }^{8}$. Human toenail samples are easy to collect, store and transport, sampling is non-invasive and they are less prone to exogenous contamination than hair samples ${ }^{8}$, making them an attractive biomarker of exposure in arsenic contaminated areas ${ }^{9}$. The ${ }_{55}$ exposure-biomarker association is subject to variation due to factors such as age, gender, recreational habits and dietary intake ${ }^{10}$. Toenail growth rates are reportedly slower in females and the elderly ${ }^{11}$ whilst consumption of seafood or foodstuffs grown in contaminated soil can both be a ${ }_{60}$ significant source of exposure ${ }^{6}$. Investigation of these factors via questionnaire data is therefore useful when employing toenails as a biomarker of exposure. The strongest As exposure-biomarker correlations have been observed when total As levels in contaminated drinking water are employed ${ }_{65}$ as the measure of exposure ${ }^{10}$. Reported As levels in the toenails of populations considered to be exposed range from 3 $\mu \mathrm{g} \mathrm{kg}^{-1},{ }^{8}$ to $37,200 \mu \mathrm{g} \mathrm{kg}^{-1},{ }^{12}$ (based on reported ranges). Lower levels are reported in unexposed or control populations ranging from $12 \mu \mathrm{g} \mathrm{kg}^{-1},{ }^{13}$ to $140 \mu \mathrm{g} \mathrm{kg}^{-1}$, ${ }^{14}$, however only 3 70 studies report control data for toenails ${ }^{12-14}$. There is little available data on background levels of arsenic in human toenails and levels at which adverse health effects are likely to be incurred. Arsenic levels of $1000 \mu \mathrm{g} \mathrm{kg}^{-1}$ in human hair 
have been associated with adverse health effect ${ }^{15}$. The Canadian government has employed a guideline level of 5000 $\mu \mathrm{g} \mathrm{kg}^{-1}$ to indicate a significant increase in exposure ${ }^{16}$. Some evidence has been presented of a link between an increased 5 risk of skin cancer (squamous cell carcinoma) and high levels of toenail arsenic (350 to $810 \mu \mathrm{g} \mathrm{kg}^{-1}$ ) ${ }^{17}$. In an epidemiological study conducted in Iowa, US, Freeman et al. $(2004)^{13}$ report toenail arsenic concentration and cutaneous melanoma to be positively correlated, the maximum reported

10 toenail arsenic concentration was $360 \mu \mathrm{g} \mathrm{kg}^{-1}$ in the exposed population. However, in a similar epidemiological study no correlation was observed between toenail arsenic concentration and the risk of bladder cancer ${ }^{18}$. Correlations between the total As content of toenails and As contaminated 15 drinking water have been demonstrated in numerous studies ${ }^{14}$, 19,20 . However, only a limited number of studies have investigated the speciation of As in human nails ${ }^{5,20,21}$. The toxicity of As is known to be species dependant. A better understanding of the potential toxicity of ingested As can be 20 gained through investigation of the resulting metabolites in human tissues. The pathway for inorganic arsenic metabolism involves alternating steps of reduction of $\mathrm{As}^{\mathrm{V}}$ to $\mathrm{As}^{\mathrm{III}}$ followed by oxidative methylation of $\mathrm{As}^{\mathrm{III}}$ to form the methylated arsenic metabolites with S-adenosyl-methionine as 25 the methyl donor ${ }^{22}$. Until recently inorganic arsenic, particularly $\mathrm{As}^{\mathrm{III}}$, was considered the most toxic chemical form with the methylation of inorganic arsenic considered a detoxification step. There is now strong evidence to suggest that the methylation of arsenic is a process that activates 30 arsenic as both a toxin and carcinogen ${ }^{23,24}$. Therefore the identification of As speciation in toenails may be useful in understanding the potential toxicity of ingested arsenic.

The unique geology and historic mining activities of Devon 35 and Cornwall in the UK led to widespread As contamination of the surrounding agricultural land and residential soils ${ }^{25-28}$. Several studies set out to characterise the As contamination occurring in the South West UK ${ }^{26}$, including the use of bioindicator species (earthworms) and in-vitro bioaccessibility 40 testing, to better understand the potential risks associated with exposure to As contaminated soils ${ }^{25,29}$. Elevated levels of urinary As in residents of former mining sites caused by soil ingestion have been reported in Australia ${ }^{30}$ and in two studies conducted in Devon and Cornwall in the UK ${ }^{31,32}$. However,

45 there are no reports to date on the sensitivity of toenails as a biomarker of exposure in residents living near to the former mining areas of Devon and Cornwall where environmental As levels are highly elevated. In particular the resulting As speciation in human toenails following exposure to As 50 contaminated soils is yet to be investigated.

The present pilot study aims to improve understanding of the exposure-biomarker relationship between human toenails and elevated environmental As levels. Toenail samples were ${ }_{55}$ collected from residents living near to a former As mine in Devon, UK and a control group in Nottinghamshire, UK with no anticipated As exposure in order to: (a) assess As exposure levels in residents of a former As mine by comparison to the control group and (b) compare the resulting As speciation in 60 the toenails of the two populations.

\section{Methods}

\section{Study site}

Devon Great Consols (DGC) is situated by the River Tamar in the Tavistock district of Devon (SX 426 735) and is one of ${ }_{65}$ many former mining sites in South West England. In the 1870 s, DGC along with half a dozen mines from the Callington and Tavistock area were the source of an estimated 50 percent of the world's arsenic production ${ }^{33}$. Soil arsenic concentrations across the mine site vary significantly 70 depending on their proximity to the main tailings, ranging from $204-34,000 \mathrm{mg} \mathrm{kg}^{-128,33,34}$. More specifically total As in residential soils and soils adjacent to residential properties were shown in a previous study to range from 204 to $9025 \mathrm{mg}$ $\mathrm{kg}^{-125}$. Arsenic bioaccessibility in soils in the mine area and 75 mine tailings were previously shown to be well above the 20 $\mathrm{mg} \mathrm{kg}^{-1}$ soil guideline value $(\mathrm{SGV})^{25,35}$ for gardens and allotments. The Human Bioaccessible Fraction (HBF) estimated using an in vitro Physiology Based Extraction Test (PBET) is reported to range from 10 to $30 \%$ of the total $\mathrm{As}^{25}$. ${ }_{80}$ This equates to bioaccessible As levels between 36 and 1312 $\mathrm{mg} \mathrm{kg}{ }^{-1}$ in residential soils and soils close to residential properties at $\mathrm{DGC}^{25}$, giving cause for concern in terms of potential human exposure.

\section{${ }_{85}$ Study group}

Ethical approval for this study was provided by the human ethics committee of Nottingham Trent University, UK. Residents living in properties on and around the former mining site of DGC were recruited by post. A total of 22 90 information packs were posted to 11 properties whose addresses were publicly available. A total of 8 residents from 6 properties volunteered to take part. Information packs contained details of the study, instructions for sample collection, a small sealable polythene sample bag and a 95 questionnaire. Residents were asked to allow toenails to grow for at least two weeks prior to sample collection. The self administered questionnaire was designed to provide information relevant to assessing potential exposure to As such as age, gender, time in residence at DGC, time spent 100 outdoors around the mine site, whether or not vegetables were grown and eaten from native soil and other potential dietary sources such as seafood and alcohol consumption. A comparable number of volunteers (9) with no anticipated arsenic exposures were also recruited by word of mouth from 105 Nottinghamshire, UK where soil As levels were below the current $\mathrm{SGV}$ of $20 \mathrm{mg} \mathrm{kg}^{-136}$.

\section{Reagents and standards}

All reagents used were analytical grade or better quality. All 110 aqueous solutions were prepared using deionised water (18.2 $\mathrm{M} \Omega$ Millipore, UK). A multi-element standard and Tellurium solution (SPEX CertiPrep, UK) were used as calibration standard and internal standard respectively for ICP-MS analysis. Inorganic arsenite $\left(\mathrm{As}^{\mathrm{III}}\right.$, Fisher $\left.\mathrm{UK}\right)$, arsenate $\left(\mathrm{As}^{\mathrm{V}}\right.$, 
Fisher, UK), methylarsonate $\left(\mathrm{MA}^{\mathrm{V}}\right.$, Sigma-Aldrich, UK), and dimethylarsinate $\left(\mathrm{DMA}^{\mathrm{V}}\right.$, Greyhound, UK) were used for the preparation of standards for arsenic speciation analysis. Concentrated nitric acid $\left(\mathrm{HNO}_{3}\right)$ and $30 \% \mathrm{v} / \mathrm{v}$ hydrogen 5 peroxide $\left(\mathrm{H}_{2} \mathrm{O}_{2}\right)$, (BDH Aristar, UK) were used for the dissolution of samples. Ammonium nitrate (> $99 \%)$ and aqueous ammonia (Fisher, UK) were used in preparation of the mobile phase for anion exchange chromatography.

\section{${ }_{10}$ Preparation of toenail samples}

Toenail samples were washed thoroughly following a slightly modified version of the protocol described by Slotnick et al. $(2007)^{8}$, which is comparable to several published methods ${ }^{5}$, $6,37,38$. Visible exogenous material was firstly removed using 15 plastic forceps and a clean quartz fragment. Samples were then placed in clean glass vials and sonicated for 5 minutes using $3 \mathrm{ml}$ of acetone, rinsed first with $2 \mathrm{ml}$ of deionised water then $2 \mathrm{ml}$ of acetone, sonicated for 10 minutes in $3 \mathrm{ml}$ of deionised water then twice rinsed with $3 \mathrm{ml}$ of deionised 20 water, ensuring complete submersion of the sample during each step. The final rinse solution $(3 \mathrm{ml})$ was retained for immediate analysis by ICP-MS to ensure removal of exogenous contamination was complete. The supernatants from each step of the washing procedure were combined and 25 reduced to dryness in PFA vials (Savillex, USA) on a graphite hot block at $80^{\circ} \mathrm{C}$. The residue was then reconstituted in $3 \mathrm{ml}$ of $1 \% \mathrm{HNO}_{3}$ for analysis by ICP-MS. After washing, toenails were left to dry at room temperature in a clean laminar flow hood before freeze-drying (Christ, Germany). The freeze30 dried toenails were pulverised to a fine powder using a cryogenic freezer mill in $0.5 \mathrm{ml}$ stainless steel cylinders with stainless steel slugs (Spex CertiPrep, UK). Samples were stored in a silica gel dessicator prior to weighing. Certified reference materials NIES CRM 13 human hair (NIES, ${ }_{35}$ Onogawa Japan) with a reference As value of $100 \mu \mathrm{g} \mathrm{kg}^{-1}$ and NCS ZC 81002b human hair (NCS Beijing, China) with a certified As value of $198 \pm 23 \mu \mathrm{g} \mathrm{kg}^{-1}$ were used throughout. An in-house human fingernail reference material (BGS Bulk) was also prepared using fingernail clippings collected over 40 several months from 4 healthy volunteers not exposed to elevated environmental arsenic. The clippings were pooled and prepared into a fine powder $(\sim 3000 \mathrm{mg})$ using the methods outlined.

\section{${ }_{45}$ Quantitative arsenic determination}

Toenail samples were acid digested for total As determination using a closed vessel microwave assisted digestion (MARS 5, CEM Corporation, UK). Into each vessel $4 \mathrm{ml}$ of $\mathrm{HNO}_{3}$ and 1 $\mathrm{ml}$ of $\mathrm{H}_{2} \mathrm{O}_{2}$ was added to accurately weighed pulverised 50 toenail samples and left to stand for 1 hour before sealing the vessels. The average sample mass was $57 \pm 29 \mathrm{mg}$ and $75 \pm$ $13 \mathrm{mg}$ for the exposed and control groups respectively. Several individuals from the control group provided sufficient sample for triplicate determinations. The recommended 55 sample mass of $200 \mathrm{mg}$ was used for NCS ZC 81002b, 120 mg for CRM 13 and $100 \mathrm{mg}$ for BGS Bulk. In addition, BGS
Bulk was digested in triplicate using the mean sample masses of the exposed and control groups. The microwave heating programme was: $100 \%$ power $(1200 \mathrm{~W}), 5$ minute ramp to ${ }_{60} 100{ }^{\circ} \mathrm{C}$, held for 2 minutes, ramped for 5 minutes to $200{ }^{\circ} \mathrm{C}$ then held for 30 minutes. The pressure in the system was approximately 200 psi under these conditions. This method resulted in complete sample dissolution. The solutions were transferred with MQ water to PFA vials and evaporated to ${ }_{65}$ dryness on a hotplate at $110{ }^{\circ} \mathrm{C}$. Samples were reconstituted with $1 \mathrm{ml}$ of $3 \% \mathrm{v} / \mathrm{v} \mathrm{HNO}_{3}$, heated at $50{ }^{\circ} \mathrm{C}$ for 10 minutes and then made up to $3 \mathrm{ml}$ with deionised water to give a final solution of $1 \% \mathrm{HNO}_{3}$ for direct determination via ICP-MS.

\section{${ }_{70}$ Extraction procedure for arsenic speciation}

Aqueous extraction of As species from toenail samples was performed using a closed vessel microwave system (CEM MARS 5, CEM Corporation, UK). The extraction procedure was optimised using human hair CRM NCS ZC 81002b and 75 the BGS Bulk fingernail sample. In addition, at each stage of the extraction optimisation, blank extraction solutions spiked with $10 \mu \mathrm{g} \mathrm{l}^{-1}$ of the As species As ${ }^{\mathrm{III}}$, DMA ${ }^{\mathrm{V}}$, and MA ${ }^{\mathrm{V}}$ were also heated to test species stability, specifically the formation of $\mathrm{As}^{\mathrm{V}}$ under the potentially oxidising conditions of the ${ }_{80}$ extraction procedure. From an initial temperature of $80^{\circ} \mathrm{C}$ the extraction time was increased from 15 - 60 minutes at 15 minute intervals. From the extraction time at which As recovery peaked the temperature was ramped at $10{ }^{\circ} \mathrm{C}$ intervals to the point at which species stability was 85 compromised. Optimum extraction conditions were found to be a 30 minute extraction at $100{ }^{\circ} \mathrm{C}$. Pulverised toenail samples $(30-80 \mathrm{mg})$ were accurately weighed into the HDPE microwave vessels and $5 \mathrm{ml}$ deionised water added before shaking thoroughly by hand to ensure complete wetting of the 90 sample. As the recommended sample mass of $200 \mathrm{mg}$ was used for NCS ZC $81002 \mathrm{~b}$ and $120 \mathrm{mg}$ for CRM 13, 10 and 6 $\mathrm{ml} \mathrm{MQ}$ water was added respectively to provide a comparable solid-solution ratio to that of the toenail samples. Following extraction the supernatant was recovered via syringe filtration ${ }_{95}$ through $0.45 \mu \mathrm{m}$ nylon mesh filters (Pall, UK) and stored overnight in pre washed polypropylene tubes at $<4{ }^{\circ} \mathrm{C}$.

\section{Arsenic determination by ICP-MS}

Arsenic determination in toenail digests and extracts was 100 performed by Inductively Coupled Plasma Mass Spectrometry (ICP-MS, Agilent 7500, Agilent Technologies, UK). The instrument was fitted with a micro flow concentric nebuliser and quartz Scott-type spray chamber. The instrument response for As was optimised daily. Arsenic detection was performed 105 in collision cell mode using $\mathrm{He}(4 \mathrm{l} / \mathrm{min})$ to minimise potential interferences such as that of the polyatomic ion ${ }^{40} \mathrm{Ar}+{ }^{35} \mathrm{Cl}$. Tellurium $\left(50 \mu \mathrm{g} \mathrm{l}^{-1}\right)$ was used as the internal standard ${ }^{39}$ by sample spiking. The limit of detection (LOD) for the method expressed as the mean blank signal $+3 \mathrm{SD}$ was $0.07 \mathrm{\mu g} \mathrm{kg}^{-1}$.

\section{Arsenic speciation by HPLC-ICP-MS}


A quaternary GP50-2 HPLC Pump and an AS-50 auto-sampler (Dionex, USA) with a $100 \mu$ l injection loop were coupled directly to the ICP-MS with PEEK tubing. The two instruments were coupled in such a way that the injection of $s$ each sample solution and its subsequent measurement was synchronised automatically using the ICP-MS ChemStation (Agilent, UK) software, enabling reproducible sample injections. Full details of the chromatographic system are published elsewhere ${ }^{28}$. In brief an anion exchange column

10 (PRP-X100, $250 \times 4 \mathrm{~mm}, 10 \mu \mathrm{m})$ with a guard column of the same material were used to separate the arsenic species present in the toenail extracts. Ammonium nitrate was used as the mobile phase at $\mathrm{pH} 8.65$ using a gradient elution between 4 and $60 \mathrm{mM}$ to achieve good separation for all As species 15 investigated (Figure 1).

\section{Results}

\section{Study participants}

Selected demographics for the exposed and control groups are 20 shown in Table 1. All participants were white, non smokers of British origin. The mean ages of the exposed and control groups were comparable at 46 and 41 respectively. The male to female ratio for both groups was approximately $2: 1$. The exposed group spent more hours outdoors in the local area 25 than the control group with mean values of 11 and $5 \mathrm{~h} / \mathrm{w}$ respectively. The dietary, specifically seafood and alcohol, consumption of the two groups were comparable.

\section{Total Arsenic}

30 All toenail samples were above the method limit of detection for As of $0.07 \mu \mathrm{g} \mathrm{kg}^{-1}$. The accuracy of the method was assessed by determination of total As in human hair certified reference materials (Table 2). The As concentration determined in human hair CRM NCS ZC 81002 b was $200 \pm$

$3512.8 \mu \mathrm{g} \mathrm{kg}^{-1}(\mathrm{n}=8)$ well within the certified value of $198 \pm 23$ $\mu \mathrm{g} \mathrm{kg}^{-1}$. The As concentration determined in human hair CRM NIES 13 was $98.5 \pm 6.5 \mu \mathrm{g} \mathrm{kg}^{-1}(\mathrm{n}=6)$ agreeing well with the reference value of $100 \mu \mathrm{g} \mathrm{kg}^{-1}$. The method precision was assessed by repeat analysis of the in-house BGS Bulk

40 human fingernail sample. The overall As concentration determined in BGS Bulk was $72.8 \pm 5.6 \mu \mathrm{g} \mathrm{kg}^{-1}(\mathrm{n}=7)$ using a sample mass of $100 \mathrm{mg}$. Analysis of BGS Bulk using the mean sample masses of the exposed and control groups toenail samples of 57 and $75 \mathrm{mg}$ gave arsenic recoveries of 45 $79.6 \pm 8.4 \mu \mathrm{g} \mathrm{kg}^{-1}(\mathrm{n}=3)$ and $71.0 \pm 0.2 \mu \mathrm{g} \mathrm{kg}^{-1} \quad(\mathrm{n}=3)$.

The total As concentration in toenails of the exposed group ranged from 858 to $25,981 \mu \mathrm{g} \mathrm{kg}^{-1}$ with a geometric mean of $5406 \mu \mathrm{g} \mathrm{kg}^{-1}(\mathrm{n}=8)$ (Table 1). Total arsenic concentrations in the control group toenails ranged from 73 to $273 \mu \mathrm{g} \mathrm{kg}^{-1}$ with 50 a geometric mean of $122 \mu \mathrm{g} \mathrm{kg}^{-1}(\mathrm{n}=9)$. Geometric means were used due to both datasets being positively skewed. Analysis of the wash solutions (corrected for sample mass) revealed exogenous contamination on the toenails of the exposed group ranged from 102 to $3784 \mu \mathrm{g} \mathrm{kg}^{-1}$ with a 55 geometric mean of $506 \mu \mathrm{g} \mathrm{kg}^{-1}$. All wash solutions for the exposed group were above the method limit of detection.
Exogenous As contamination on the toenails of the control group ( 3 of which were below the limit of detection) ranged from 2.1 to $12.8 \mu \mathrm{g} \mathrm{kg}^{-1}$, with a geometric mean of $4.0 \mu \mathrm{g} \mathrm{kg}$ ${ }_{60}{ }^{1}$. Arsenic was detected in 6 out of 8 final rinse solutions for the exposed group ranging from 10 to $214 \mu \mathrm{g} \mathrm{kg}^{-1}$ with a geometric mean of $37 \mu \mathrm{g} \mathrm{kg}^{-1}$. In the control group only 3 out of 9 final rinse solutions contained detectable levels of As ranging from 1.0 to $3.8 \mu \mathrm{g} \mathrm{kg}^{-1}$ with a geometric mean of 2.0 ${ }_{65} \mu \mathrm{g} \mathrm{kg}^{-1}$.

\section{Optimisation of extraction procedure for As speciation}

The impact of increased extraction time (extraction temperature $=80^{\circ} \mathrm{C}$ ) on the recovery of As species from BGS ${ }_{70}$ Bulk fingernail reference sample and Human hair CRM ZC81002b are displayed in Figures $2 \mathrm{a}$ and $2 \mathrm{~b}$ respectively. The extraction efficiency (extracted As / total As $\times 100$ ) for ZC81002b peaked at 30 minutes but continued to increase with time up to 60 minutes for BGS Bulk. The recovery of $75 \mathrm{As}^{\mathrm{V}}$ was greatest at 30 minutes for both samples with a trend of decreasing recovery of $\mathrm{As}^{\mathrm{V}}$ with time most evident in the BGS Bulk sample. Recovery of the remaining As species detected in BGS Bulk ( $\mathrm{As}^{\mathrm{III}}$ and $\mathrm{DMA}^{\mathrm{V}}$ ) showed a gradual increase with increasing extraction time. For CRM ZC 81002b

80 extraction times above 30 minutes had little impact on the recovery of the detected As species $\left(\mathrm{As}^{\mathrm{V}}, \mathrm{As}^{\mathrm{III}}, \mathrm{DMA}^{\mathrm{V}}\right.$ and $\mathrm{MA}^{\mathrm{V}}$ ). For this reason 30 minutes was taken as the optimum extraction time for investigating the effects of increased temperature on species recovery. Figures $2 \mathrm{c}$ and $2 \mathrm{~d}$ display 85 the effects of increasing temperature on the species recovery for the same two samples. BGS Bulk fingernail sample demonstrated a gradual increase in species recovery with each temperature increment with the proportion of species remaining fairly constant. Increasing extraction temperature 90 had a lesser impact on the recovery of species from the hair CRM ZC81002b with the exception of increased recovery of $\mathrm{As}^{\mathrm{III}}$ between 80 and $100{ }^{\circ} \mathrm{C}$. No inter-conversion of species was observed in the blank solutions spiked with $10 \mu \mathrm{g} \mathrm{l}^{-1}$ of each As species and subjected to the extraction cycle (Table $953)$ with good recovery of all species under the chromatographic conditions employed. A limited supply of the BGS Bulk reference sample precluded further optimisation of the extraction procedure therefore the method applied to toenail samples, based on the present findings, was taken as a 10030 minute extraction at $100{ }^{\circ} \mathrm{C}$.

\section{As speciation in toenails}

Determination of As species in toenail extracts via HPLCICP-MS was performed where sufficient sample material was 105 provided by the participant. This equated to two participants in the exposed group and five participants in the control group. Table 2 displays data relating to the extraction and speciation of As in these toenail samples, the human hair reference materials and the BGS Bulk fingernail sample. The 110 extraction procedure employed resulted in a mean recovery of As from toenails of $53 \pm 12 \%(n=7)$. The highest As recovery was obtained for the BGS Bulk fingernail sample at 
$70 \%$. The two human hair reference materials ZC $81002 \mathrm{~b}$ and CRM13 gave differing As recoveries of 60 and $44 \%$, respectively. The mean column recovery for toenail samples was $94 \pm 7 \%(\mathrm{n}=7)$. An HPLC-ICP-MS chromatogram 5 demonstrating the peak retention and resolution for investigated As species is shown in Figure 1. The proportional As speciation observed in the reference materials and toenail samples under investigation are displayed in Figure 3. The dominant species extracted from toenail samples was 10 inorganic $\mathrm{As}^{\mathrm{III}}$ at an average proportion of $83 \pm 9 \%(n=7)$. Inorganic $\mathrm{As}^{\mathrm{V}}$ was present in all the toenail extracts but a lower mean proportion was extracted at $13 \pm 8 \%(\mathrm{n}=7)$. $\mathrm{DMA}^{\mathrm{V}}$ was detected in 6 of the 7 toenail extracts at an average proportion of $4 \pm 3 \%(\mathrm{n}=6)$, with $\mathrm{MA}^{\mathrm{V}}$ only 15 detectable in the 2 samples from the exposed group at less than $1 \%$ of the extracted As.

\section{Discussion}

Total As concentrations in toenails from the exposed group 20 are elevated compared to the control group with geometric means of 5406 and $122 \mu \mathrm{g} \mathrm{kg}^{-1}$ respectively. The Wilcoxon Signed Rank Test (SPSS version 14) revealed the difference between the exposed and control groups was significant $(\mathrm{p}<$ 0.05 ). The increased number of hours spent outdoors by the ${ }_{25}$ exposed population may be significant in providing increased exposure to environmental As (Table 1). Other potentially influential factors such as age, gender and diet were comparable between the two groups. The toenail As concentration range of the exposed group in this study (858 to $3025,981 \mu \mathrm{g} \mathrm{kg}^{-1}$ ) falls within the overall range reported in the literature (Figure 4) of 3 to $37,200 \mu \mathrm{g} \mathrm{kg}^{-1}$ for exposed populations. The geometric mean toenail As concentration (122 $\mu \mathrm{g} \mathrm{kg}^{-1}$ ) for the control group is comparable with values reported in the literature for non-exposed individuals at $40 \mu \mathrm{g}$ $35 \mathrm{~kg}^{-113}$ and $140 \mu \mathrm{g} \mathrm{kg}^{-114}$. Toenail As concentrations in excess of the maximum reported in this study $\left(25,981 \mu \mathrm{g} \mathrm{kg}^{-1}\right)$ have only been reported in the study by Hinwood et al. $(2003)^{12}$, who found an upper range concentration of $37,200 \mu \mathrm{g} \mathrm{kg}^{-1}$ in the toenails of individuals living in areas with high 40 environmental As concentrations. Failure to quantify the degree of exogenous contamination was cited as a limitation of the study. In the present study, quantification of exogenous As contamination revealed significantly $(p=<0.05)$ higher levels of exogenous As on the toenails of the exposed group 45 compared to the control group using the Wilcoxon Signed Rank Test. Exogenous As contamination was also positively correlated with total toenail As (Figure 5). Quantification of exogenous As in this way provides a useful measure of environmental As levels for the two study populations, 50 highlighting the high levels of environmental As in the exposed population by comparison to the control group (Table 1). The very low levels of As in the final rinse solutions for both groups suggested that the toenail washing procedure was effective in removing exogenous contamination, however ${ }_{55}$ more As was present in the final rinse solutions of the exposed group. The As observed in the final rinse solutions from the toenail washing procedure may be due to very low levels being leached out during the final rinse step. Mandal et al. $(2003)^{5}$ found that As was released from pre-washed ${ }_{60}$ fingernail samples after soaking at room temperature in deionised water although the amount of As leached was reported to be negligible at 0.4 to $1.4 \%$ of the total As in the fingernails. In the present study the As content observed in the final rinse solutions was also negligible ranging from 0.2 to ${ }_{65} 1.6 \%$ of the total As in the toenail samples.

Several previous studies have investigated As exposure in the South West of England. In a limited study Johnson and Farmer $(1987)^{31}$ noted slightly elevated levels of urinary As in ${ }_{70}$ Cornwall residents. Kavanagh et al. $(1998)^{32}$ found significantly higher $(p=0.01)$ levels of total As in the urine of residents at DGC and the nearby town of Gunnislake compared to residents of an uncontaminated area. These papers conclude that the studied populations at DGC and ${ }_{75}$ Gunnislake were chronically exposed to As and that exposure resulted from the ingestion of As contaminated soil and dust. The use of urine as a biomarker of As exposure is more suited to assessing acute exposure since arsenic is excreted in the urine within hours of ingestion ${ }^{10}$, whereas toenails provide an 80 integrated measure of exposure over a longer period, $12-18$ months prior to sample collection ${ }^{8}$. For this reason toenails may represent a more suitable biomarker of exposure in populations chronically exposed to As.

${ }_{85}$ During optimisation of the extraction procedure, the recovery of $\mathrm{As}^{\mathrm{V}}$ from both the BGS Bulk fingernail sample and the human hair CRM ZC 81002 b peaked after extracting for 30 minutes at $80{ }^{\circ} \mathrm{C}$ (Figure $2 \mathrm{a} / \mathrm{b}$ ). It can also be observed from Figure $2 \mathrm{a}$ that after 30 minutes the recovery of $\mathrm{As}^{\mathrm{III}}$ increases 90 slightly whilst $\mathrm{As}^{\mathrm{V}}$ recovery decreases. Similar trends were reported by Mandal et al. $(2003)^{5}$ who found that $\mathrm{As}^{\mathrm{V}}$ was reduced to $\mathrm{As}^{\mathrm{III}}$ when fingernail samples were soaked at room temperature for 72 hours, suggesting the reducing capacity of fingernails in aqueous solution. Raab and Feldman $(2005)^{40}$ 95 suggested that boiling releases or activates strong reducing agents in human hair and reported the transformation of $\mathrm{DMA}^{\mathrm{V}}$ to its sulphur analogue DMAS. The results presented here (Figure 2a-d) suggest that at temperatures below $100^{\circ} \mathrm{C}$, extraction time is more influential on the reduction of ${ }_{100}$ pentavalent arsenic species, as the recovery of $\mathrm{As}^{\mathrm{V}}$ is more constant across the temperature range of 80 to $100{ }^{\circ} \mathrm{C}(30$ minute extraction time) than across the extraction time range of 15 to 60 minutes $\left(80^{\circ} \mathrm{C}\right.$ extraction temperature).

105 The microwave assisted extraction method developed in this study achieved a mean recovery of As from toenail samples of $53 \%$ (Table 2). There are few reported studies to which this extraction efficiency can be compared. Raab and Feldman $(2005)^{40}$ reported an extraction efficiency of $57 \pm 26 \%$ in hair 110 samples using boiling water for 6 hours, but with species instabilities. Shraim et al. $(2001)^{41}$ reported a $39 \%$ extraction efficiency for CRM 13 when shaken for 30 minutes with water. For comparison the extraction method presented here achieved a slightly improved recovery of As from CRM 13 of $11544 \%$ (Table 2). In a study on As speciation in human 
fingernails and hair from an As-affected area, Mandal et al. $(2003)^{5}$ report a mean recovery of As in fingernails of $63 \%$ (range 50 to $75 \%$ ) using a 30 minute water extraction at 90 ${ }^{\circ} \mathrm{C}$, slightly higher than the $53 \%$ recovery of As from toenails 5 reported in this study. However the extraction method developed in the present study achieved an As recovery of 70 $\%$ (Table 2) when applied to the BGS Bulk fingernail sample. This suggests that As is more strongly bound in toenails than fingernails.

Arsenic speciation data for human hair CRM 13 were reported in two previous studies. Mandal et al. $(2003)^{5}$ reported As ${ }^{\mathrm{III}}$ to be the dominant species present at $56 \%$ with lesser amounts of $\mathrm{As}^{\mathrm{V}}$ and $\mathrm{DMA}^{\mathrm{V}}$ at $35 \%$ and $9 \%$ respectively. Shraim et al. $15(2001)^{41}$ reported very different proportions of each As species with $\mathrm{As}^{\mathrm{V}}$ present at $66 \%$ of extracted As, whilst the remaining As was found to be divided into similar amounts between $\mathrm{As}^{\mathrm{III}}, \mathrm{DMA}^{\mathrm{V}}$ and $\mathrm{MA}^{\mathrm{V}}$ at $16 \%, 7 \%$ and $11 \%$ respectively. In the present study $\mathrm{As}^{\mathrm{III}}$ and $\mathrm{As}^{\mathrm{V}}$ were found to 20 be present in similar proportions of $44 \%$ and $47 \%$ of the extracted As (Figure 3) with $\mathrm{DMA}^{\mathrm{V}}$ present at $9 \%$. Species stability under the extraction procedure employed was reported in both the two previous studies and in the present study. However, only the proportion of $\mathrm{DMA}^{\mathrm{V}}$ reported is

${ }_{25}$ comparable across the three studies. This may be due to the differing extraction procedures employed and the subsequent extraction efficiencies. Both Mandal et al. (2003) $)^{5}$ and Shraim et al. $(2001)^{41}$ used water as the sole extractant. Mandal et al. $(2003)^{5}$ heated their samples to $90{ }^{\circ} \mathrm{C}$ for 30 minutes, 30 achieving a $98 \%$ As recovery. Shraim et al. $(2001)^{41}$ employed mechanical shaking at ambient temperature achieving a lower extraction efficiency of $39 \%$. The extraction procedure employed in the present study is more comparable to the method used by Mandal et al. $(2003)^{5}$ and

35 likewise resulted in more comparable results for As speciation in human hair CRM 13. This disparity between the reported As speciation in CRM 13 highlights the need for reproducible extraction methodologies if As speciation is to be incorporated into studies looking at biomarkers of exposure to

40 As in human populations. In a study of As in the hair and nails of individuals exposed to As-rich groundwaters in Kandal province, Cambodia, Gault et al. $(2008)^{20}$ used X-ray absorption near edge structure (XANES) spectroscopy to probe the As speciation of fingernail samples directly, 45 precluding the necessity of an extraction step. Using XANES spectroscopy Gault et al. $(2008)^{20}$ reported $\mathrm{As}^{\mathrm{III}}$ to be the principal As species in fingernail samples but found considerable variability between samples and problems with the fitting of spectra were reported. In the present study 50 inorganic $\mathrm{As}^{\mathrm{III}}$ was the dominant As species in toenail samples consistently (Figure 3) with lesser amounts of $\mathrm{As}^{\mathrm{V}}$ and $\mathrm{DMA}^{\mathrm{V}}$. Arsenic speciation was similar in the toenails of both the control and exposed samples analysed. The only notable difference was the detection of small amounts of $\mathrm{MA}^{\mathrm{V}}$ in the ${ }_{55}$ two toenail samples from the exposed group and is likely due to the higher As concentration in the toenails of the exposed group giving rise to detectable levels of $\mathrm{MA}^{\mathrm{V}}$.

\section{Conclusion}

${ }_{60}$ The As concentrations observed in the toenail samples collected from residents of the former mine site (DGC) are elevated suggesting chronic exposure to high environmental As. The quantification of exogenous As contamination on the toenails of both the exposed and control groups in this study ${ }_{65}$ provides a useful measure of environmental As levels as evidence of the extent of potential As exposure. A positive correlation between exogenous toenail As (removed during the wash procedure) and total toenail As demonstrates a link between the source of exposure (environmental As) and 70 toenail As content. Inorganic As ${ }^{\text {III }}$ is the dominant extractable As species in toenail samples from both the exposed and control group with lower amounts of inorganic $\mathrm{As}^{\mathrm{V}}$ and $\mathrm{DMA}^{\mathrm{V}}$. The data presented highlights the sensitivity of toenails as a biomarker of exposure to high environmental As 75 in areas such as the South west, UK where historic mining activity has led to widespread As contamination.

\section{Acknowledgments}

Funding for this research was provided by the British ${ }_{80}$ Geological Survey University Funding Initiative (BUFI). We thank the participants for taking part in this research. We also thank Dr Timothy Heaton for providing assistance with sample preparation at the NERC Isotope Geosciences Laboratory (NIGL) and Dr Mark Cave for reviewing the 85 manuscript.

\section{References}

1. B. K. Mandal and K. T. Suzuki, Talanta, 2002, 58, 201-235.

2. T. Yoshida, H. Yamauchi and G. Fan Sun, Toxicol. Appl. Pharmacol., 2004, 198, 243-252.

3. M. R. Karagas, T. A. Stukel and T. D. Tosteson, Int. J. Hyg. Environ. Health., 2002, 205, 85-94.

4. A. P. Decaprio, Environ. Sci. Technol., 1997, 31, 1837-1848.

5. B. K. Mandal, Y. Ogra and K. T. Suzuki, Toxicol. Appl. Pharmacol., 2003, 189, 73-83.

6. M. Wilhelm, B. Pesch, J. Wittsiepe, P. Jakubis, P. Miskovic, T. Keegan, M. J. Nieuwenhuijsen and U. Ranft, Journal of Exposure Analysis and Environmental Epidemiology, 2005, 15, 89-98.

7. H. C. Hopps, Sci. Total Environ., 1977, 7, 71-89.

100 8. M. J. Slotnick, J. R. Meliker, G. A. Avruskin, D. Ghosh and J. O. Nriagu, Journal of Toxicology and Environmental Health - Part A: Current Issues, 2007, 70, 148-158.

9. J. B. Wickre, C. L. Folt, S. Sturup and M. R. Karagas, Archives of Environmental Health, 2004, 59, 400-409.

105 10. M. J. Slotnick and J. O. Nriagu, Environ. Res., 2006, 102, 125-139.

11. A. S. Geyer, N. Onumah, H. Uyttendaele and R. K. Scher, Journal of the American Academy of Dermatology, 2004, 50, 229-234.

12. A. L. Hinwood, M. R. Sim, D. Jolley, N. de Klerk, E. B. Bastone, J. Gerostamoulos and O. H. Drummer, Environ. Health Perspect.,

$110 \quad 2003, \mathbf{1 1 1}, 187-193$.

13. L. E. B. Freeman, L. K. Dennis, C. F. Lynch, P. S. Thorne and C. L. Just, American Journal of Epidemiology, 2004, 160, 679-687. 
14. M. R. Karagas, J. S. Morris, J. E. Weiss, V. Spate, C. Baskett and E. R. Greenberg, Cancer Epidemiology Biomarkers and Prevention, 1996, 5, 849-852.

15. J. T. Hindmarsh and R. F. McCurdy, Critical reviews in clinical laboratory sciences, 1986, 23, 315-347.

16. T. C. Pan, T. H. Lin, C. L. Tseng, M. H. Yang and C. W. Huang, Biol. Trace Elem. Res., 1993, 39, 117-128.

17. M. R. Karagas, T. A. Stukel, J. S. Morris, T. D. Tosteson, J. E. Weiss, S. K. Spencer and E. R. Greenberg, American Journal of

10 Epidemiology, 2001, 153, 559-565.

18. D. S. Michaud, M. E. Wright, K. P. Cantor, P. R. Taylor, J. Virtamo and D. Albanes, American Journal of Epidemiology, 2004, 160, 853859.

19. M. L. Kile, E. A. Houseman, C. V. Breton, Q. Quamruzzaman, M.

15 Rahman, G. Mahiuddin and D. C. Christiani, Journal of Environmental Science and Health - Part A Toxic/Hazardous Substances and Environmental Engineering, 2007, 42, 1827-1834.

20. A. G. Gault, H. A. L. Rowland, J. M. Charnock, R. A. Wogelius, I. Gomez-Morilla, S. Vong, M. Leng, S. Samreth, M. L. Sampson and

20 D. A. Polya, Sci. Total Environ., 2008, 393, 168-176.

21. E. Sanz, R. Munoz-Olivas, C. Camara, M. K. Sengupta and S. Ahamed, Journal of Environmental Science and Health - Part A Toxic/Hazardous Substances and Environmental Engineering, 2007, 42, 1695-1705.

25 22. T. W. Gebel, Int. J. Hyg. Environ. Health., 2001, 203, 249-262.

23. K. T. Kitchin, Toxicol. Appl. Pharmacol., 2001, 172, 249-261.

24. M. Styblo, Z. Drobna, I. Jaspers, S. Lin and D. J. Thomas, Environ. Health Perspect., 2002, 110, 767-771.

25. M. Button, M. J. Watts, M. Cave, C. F. Harrington and G. R. T.

30 Jenkin, Environ. Geochem. Health, 2008, In Press, DOI: 10.1007/s10653-10008-19208-10653.

26. G. S. Camm, H. J. Glass, D. W. Bryce and A. R. Butcher, J. Geochem. Explor., 2004, 82, 1-15.

27. J. T. van Elteren, Z. Slejkovec, I. Arcon and H. J. Glass, Environ. Pollut., 2006, 139, 477-488.

28. M. J. Watts, M. Button, T. S. Brewer, G. R. T. Jenkin and C. F. Harrington, J. Environ. Monit., 2008, 10, 753-759.

29. C. J. Langdon, T. G. Piearce, A. A. Meharg and K. T. Semple, Environ. Pollut., 2003, 124, 361-373.

40 30. A. L. Hinwood, M. R. Sim, D. Jolley, N. de Klerk, E. B. Bastone, J. Gerostamoulos and O. H. Drummer, Environ. Geochem. Health, 2004, 26, 27-36.

31. L. R. Johnson and J. G. Farmer, Environ. Geochem. Health, 1989, 11, 39-44.

45 32. P. Kavanagh, M. E. Farago, I. Thornton, W. Goessler, D. Kuehnelt, C. Schlagenhaufen and K. J. Irgolic, Analyst, 1998, 123, 27-29.

33. B. A. Klinck, B. Palumbo, M. R. Cave and J. Wragg, Arsenic dispersal and bioaccessibility in mine contaminated soils: a case study from an abandoned arsenic mine in Devon, UK, Research

50 Report RR/04/003, British Geological Survey, Nottingham, 2002.

34. C. J. Langdon, T. G. Piearce, A. A. Meharg and K. T. Semple, Soil Biol. Biochem., 2001, 33, 1239-1244.

35. M. R. Cave, J. Wragg, B. Palumbo and B. A. Klinck, Measurement of the Bioaccessibility of Arsenic in UK Soils, R \& D Technical Report
36. A. J. Scheib and S. E. Nice, Soil geochemical baseline data for the urban areas of Corby, Coventry, Derby, Leicester, Northampton, Nottingham and Peterborough in the East Midlands, Internal Report IR/06/023, British Gelogical Survey, Nottingham, 2008.

60 37. E. I. Brima, P. I. Haris, R. O. Jenkins, D. A. Polya, A. G. Gault and C. F. Harrington, Toxicol. Appl. Pharmacol., 2006, 216, 122-130.

38. M. R. Karagas, T. D. Tosteson, J. Blum, B. Klaue, J. E. Weiss, V. Stannard, V. Spate and J. S. Morris, American Journal of Epidemiology, 2000, 152, 84-90.

65 39. J. Entwisle and R. Hearn, Spectrochimica Acta - Part B Atomic Spectroscopy, 2006, 61, 438-443.

40. A. Raab and J. Feldmann, Anal. Bioanal. Chem., 2005, 381, 332-338.

41. A. Shraim, S. Hirano and H. Yamauchi, Anal. Sci., 2001, 17, 17291723 .

70

Notes and references

${ }^{a}$ British Geological Survey, Keyworth, Nottingham, UK, NG12 5GG.

Fax: 0115 9363200; Tel: 0115 9363100; E-mail: mbutton@bgs.ac.uk and mwatts@bgs.ac.uk

$7{ }^{b}$ Department of Geology, University of Leicester, Leicester, UK. Fax:

0116 2523981; Tel: 0116 2523934; E-mail: grtj1@leicester.ac.uk

' School of Science and Technology, Nottingham Trent University,

Nottingham, UK. Tel: 0115 8483169; E-mail:

Christopher.harrington@ntu.ac.uk 80 


\section{Tables and Figures}

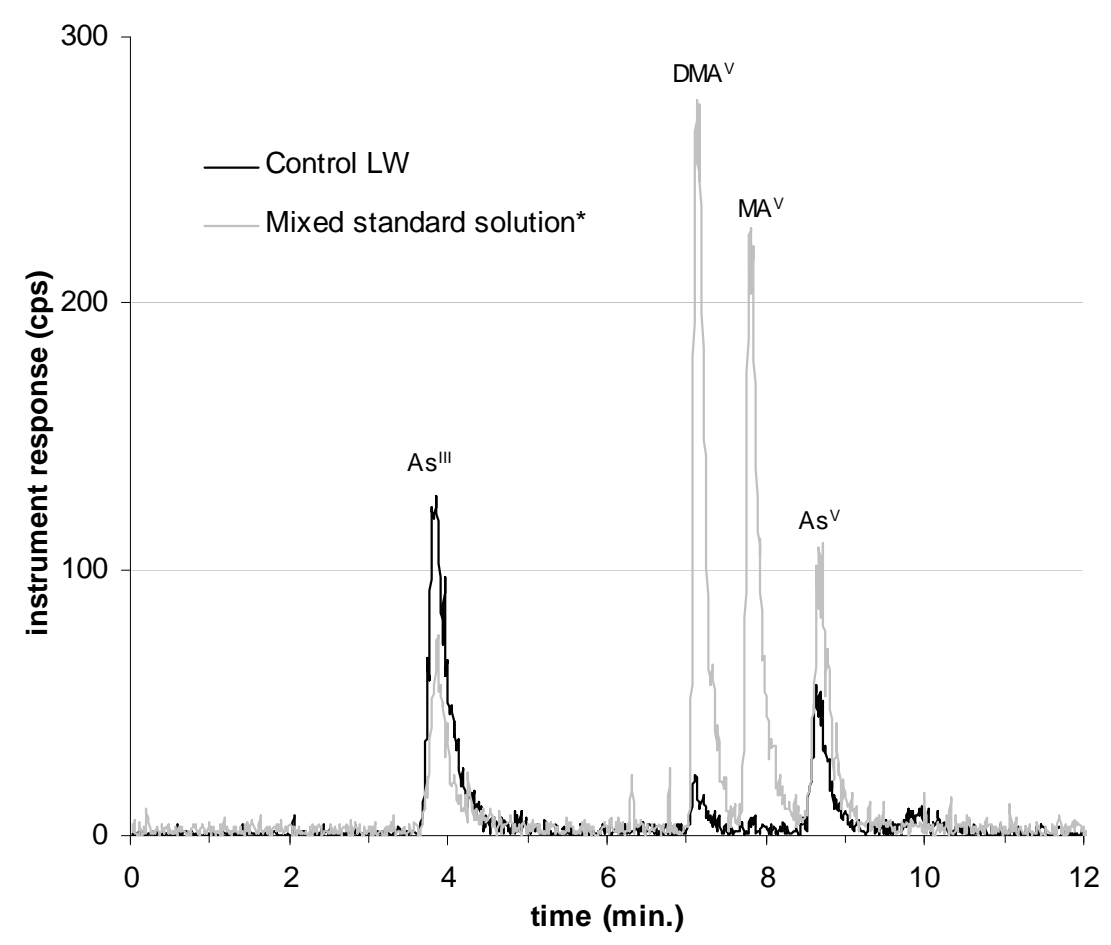

Figure 1: HPLC-ICP-MS chromatogram of a mixed standard solution (As ${ }^{\mathrm{III}}$ and $\mathrm{As}^{\mathrm{V}}$ at $0.2 \mu \mathrm{g} \mathrm{l}^{-1}$, $\mathrm{DMA}^{\mathrm{V}}$ and $\mathrm{MA}^{\mathrm{V}}$ at $0.5 \mu \mathrm{g} \mathrm{l}^{-1}$ ) and toenail extract Control LW. 


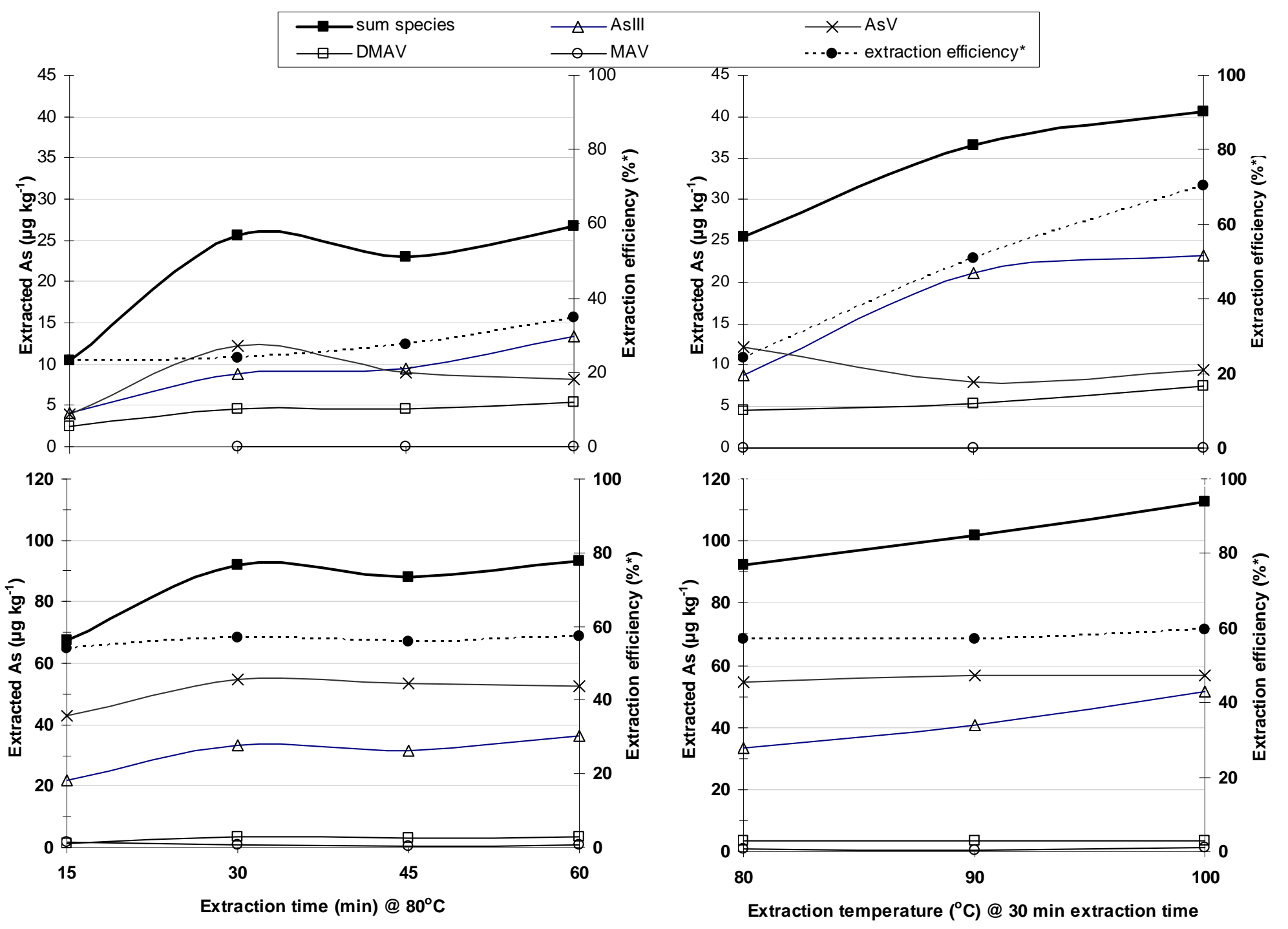

Figure 2: Effect of extraction time at $80{ }^{\circ} \mathrm{C}$ on the recovery of As species from (a) BGS Bulk fingernail reference sample and (b) Human hair CRM ZC81002b. Effect of extraction temperature with a 30 minute extraction time on the recovery of As species from (c) BGS Bulk fingernail reference sample and (d) Human hair CRM ZC81002b. * = extracted As / total As x 100. 


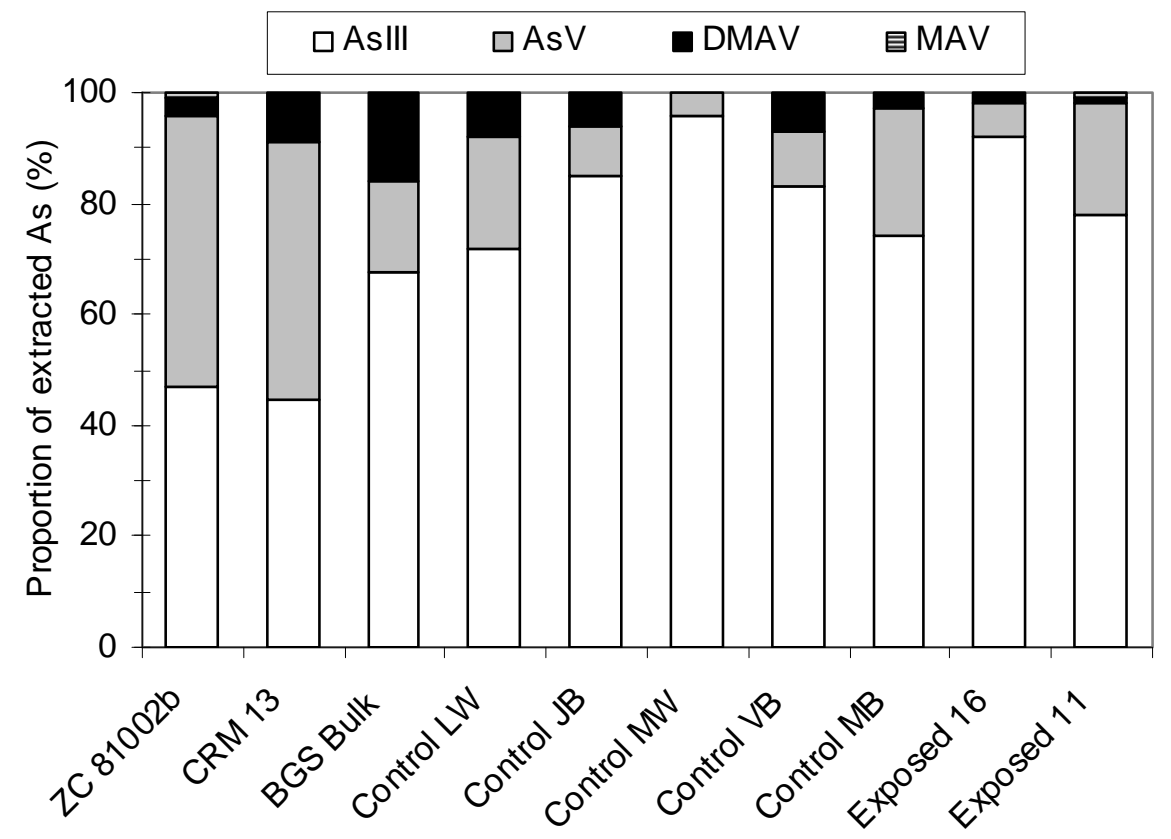

Figure 3: Individual As species as a percentage of the extracted As for each sample investigated. Toenail samples (Control LW onwards) are plotted in order of increasing total As.

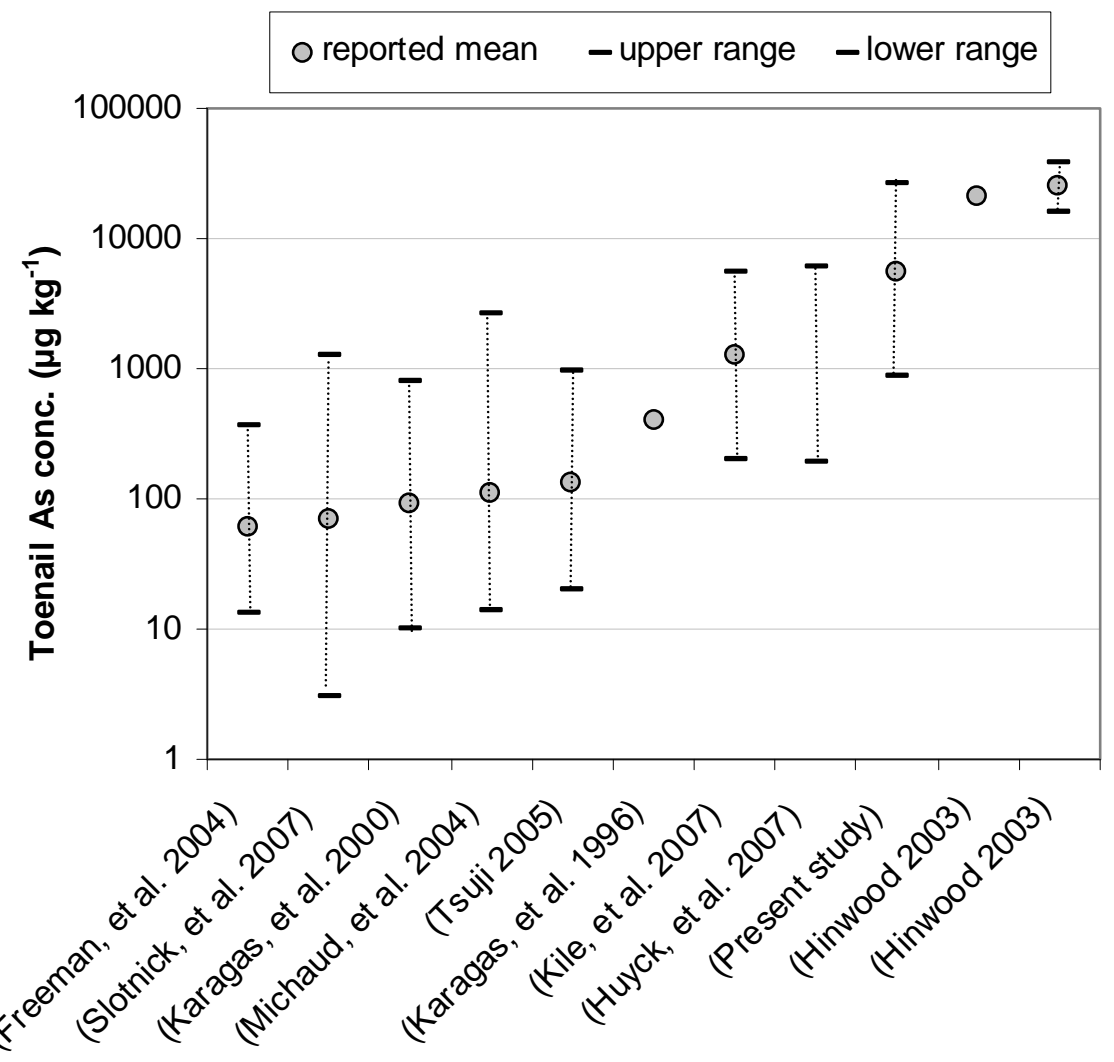

Figure 4: Comparison of the toenail As content of exposed populations reported in recent studies to that in the exposed group in the present study. 


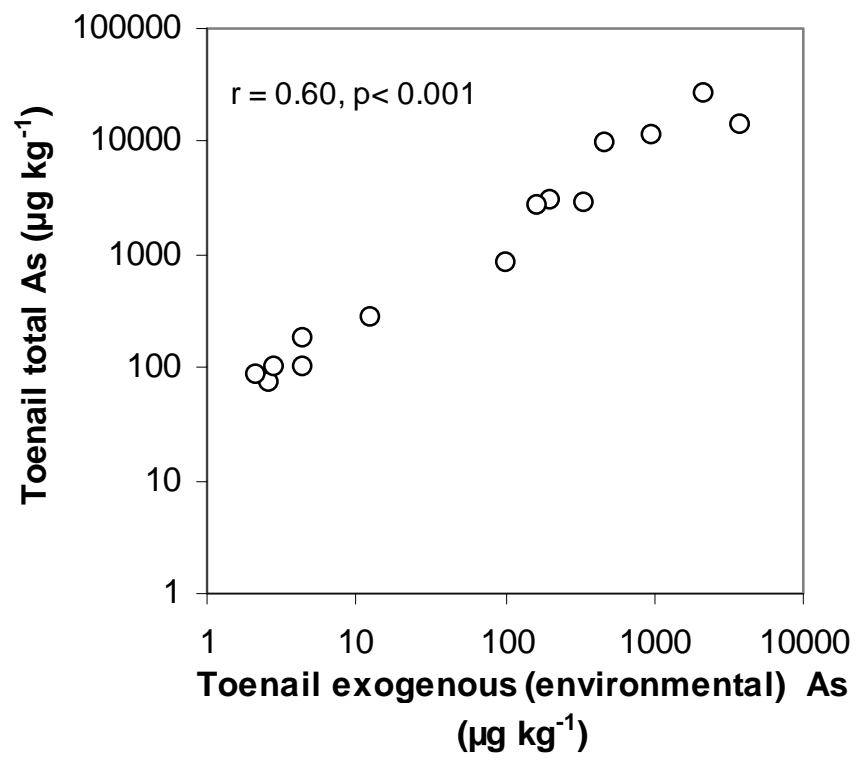

Figure 5: Correlation between toenail exogenous As contamination (environmental As) and toenail total As content. Based on exposed and control datasets combined.

Table 1: Summarised demographic, toenail As concentration and exogenous toenail contamination data for the exposed and control groups. ${ }^{*}=$ geometric mean

\begin{tabular}{|c|c|c|c|c|c|c|}
\cline { 2 - 6 } \multicolumn{1}{c|}{} & \multicolumn{3}{c|}{ Exposed group } & \multicolumn{3}{c|}{ Control group } \\
\cline { 2 - 7 } \multicolumn{1}{c|}{} & mean \pm SD & min & max & mean \pm SD & min & max \\
\hline Age & $46 \pm 26$ & 11 & 67 & $41 \pm 13$ & 25 & 55 \\
Male/Female (n) & $5 / 3$ & & & $6 / 3$ & & \\
hours outdoors (per week) & $11 \pm 7$ & 3 & 21 & $5 \pm 2$ & 2 & 10 \\
Toenail As $\left(\mu g \mathrm{~kg}^{-1}\right)$ & $5406 *$ & 858 & 25981 & $122^{*}$ & 73 & 273 \\
Exogenous toenail As $\left(\mu \mathrm{g} \mathrm{kg}^{-1}\right)$ & $506 *$ & 102 & 3784 & $4.0 *$ & 2.1 & 13 \\
\hline
\end{tabular}


Table 2: Data relating to the extraction and speciation of As in reference materials and toenail samples. Certified total As value for ZC 81002b and reference value for CRM 13 are shown in brackets. Extraction efficiency = extracted As / total As x 100. Column recovery $=$ sum species $/$ extracted As $\times 100 . *=$ single determination. $<$ LOD = below limit of detection.

\begin{tabular}{|c|c|c|c|c|c|c|c|c|c|}
\hline \multirow[b]{2}{*}{$\begin{array}{c}\text { Sample } \\
\text { mean }\end{array}$} & \multirow[b]{2}{*}{$\begin{array}{l}\text { Total As } \\
\left(\mu g \mathrm{~kg}^{-1}\right)\end{array}$} & \multirow{2}{*}{$\begin{array}{c}\text { Extracted } \\
\text { As } \\
\left(\mu \mathrm{gg}^{-1}\right)\end{array}$} & \multirow{2}{*}{$\begin{array}{c}\text { Extraction } \\
\text { efficiency } \\
(\%)\end{array}$} & \multicolumn{4}{|c|}{ As species $\left(\mu \mathrm{gg}^{-1}\right)$} & \multirow{2}{*}{$\begin{array}{c}\text { Sum } \\
\text { species } \\
\left.(\mu \mathrm{g} \mathrm{kg})^{-1}\right)\end{array}$} & \multirow{2}{*}{$\begin{array}{c}\text { Column } \\
\text { recovery } \\
(\%)\end{array}$} \\
\hline & & & & $\mathbf{A s}^{\mathrm{III}}$ & DMA $^{\mathbf{V}}$ & $\mathbf{M A}^{\mathbf{V}}$ & $\mathrm{As}^{\mathrm{V}}$ & & \\
\hline $\begin{array}{c}\text { ZC 81002b } \\
S D(n=8)\end{array}$ & $\begin{array}{c}200(198) \\
13\end{array}$ & $\begin{array}{c}119 \\
6.1\end{array}$ & 60 & $\begin{array}{l}51 \\
29\end{array}$ & $\begin{array}{l}2.9 \\
0.7\end{array}$ & $\begin{array}{l}0.9 \\
0.7\end{array}$ & $\begin{array}{l}53 \\
4.8\end{array}$ & $\begin{array}{l}108 \\
6.9\end{array}$ & 91 \\
\hline $\begin{array}{l}\text { CRM 13 } \\
S D(n=6)\end{array}$ & $\begin{array}{c}99(100) \\
6.5\end{array}$ & $\begin{array}{l}43 \\
2.8\end{array}$ & 44 & $\begin{array}{l}19 \\
3.1\end{array}$ & $\begin{array}{l}3.7 \\
1.9\end{array}$ & $<\mathrm{LOD}$ & $\begin{array}{c}20 \\
4.13\end{array}$ & $\begin{array}{l}43 \\
4.4\end{array}$ & 100 \\
\hline $\begin{array}{l}\text { BGS Bulk } \\
S D(n=13)\end{array}$ & $\begin{array}{l}74 \\
6.2\end{array}$ & $\begin{array}{l}51 \\
6.8\end{array}$ & 70 & $\begin{array}{l}27 \\
5.3\end{array}$ & $\begin{array}{l}6.4 \\
2.8\end{array}$ & $<\mathrm{LOD}$ & $\begin{array}{l}6.5 \\
3.4\end{array}$ & $\begin{array}{l}40 \\
5.8\end{array}$ & 78 \\
\hline $\begin{array}{c}\text { Control LW } \\
(S D(n=3)\end{array}$ & $\begin{array}{l}85 \\
37\end{array}$ & $\begin{array}{l}33 \\
7.9\end{array}$ & 39 & $\begin{array}{l}22 \\
5.2\end{array}$ & $\begin{array}{l}2.3 \\
0.2\end{array}$ & $<\mathrm{LOD}$ & $\begin{array}{l}6.7 \\
6.0 \\
1.5\end{array}$ & $\begin{array}{l}30 \\
4.2\end{array}$ & 91 \\
\hline Control JB* & 99 & 52 & 52 & 44 & 3.3 & $<\mathrm{LOD}$ & 4.9 & 52 & 100 \\
\hline $\begin{array}{c}\text { Control MW } \\
S D(n=3)\end{array}$ & $\begin{array}{c}101 \\
3.1\end{array}$ & $\begin{array}{l}59 \\
9.7\end{array}$ & 59 & $\begin{array}{l}51 \\
3.2\end{array}$ & $<\mathrm{LOD}$ & $<\mathrm{LOD}$ & $\begin{array}{l}2.2 \\
2.3\end{array}$ & $\begin{array}{l}53 \\
1.7\end{array}$ & 90 \\
\hline $\begin{array}{c}\text { Control VB } \\
S D(n=3)\end{array}$ & $\begin{array}{c}184 \\
28\end{array}$ & $\begin{array}{l}69 \\
19\end{array}$ & 38 & $\begin{array}{l}49 \\
17\end{array}$ & $\begin{array}{l}3.9 \\
1.6\end{array}$ & $<\mathrm{LOD}$ & $\begin{array}{l}5.8 \\
4.8\end{array}$ & $\begin{array}{l}59 \\
14\end{array}$ & 86 \\
\hline $\begin{array}{c}\text { Control MB } \\
S D(n=3)\end{array}$ & $\begin{array}{c}273 \\
17\end{array}$ & $\begin{array}{c}161 \\
19\end{array}$ & 59 & $\begin{array}{c}115 \\
4.3\end{array}$ & $\begin{array}{l}3.9 \\
0.2\end{array}$ & $<\mathrm{LOD}$ & $\begin{array}{l}36 \\
3.2\end{array}$ & $\begin{array}{c}155 \\
10\end{array}$ & 96 \\
\hline Exposed 16* & 2987 & 2031 & 68 & 1743 & 37 & 6.4 & 106 & 1892 & 93 \\
\hline Exposed 11* & 25981 & 14176 & 55 & 11477 & 84 & 73 & 2899 & 14533 & 103 \\
\hline
\end{tabular}

Table 3: Recovery of As species from blank extraction solutions spiked with $10 \mu \mathrm{g} \mathrm{l}^{-1}$ of each species at each step in the optimisation of extraction procedure. Errors are $1^{*}$ $\mathrm{SD}(\mathrm{n}=3)$.

\begin{tabular}{|c|c|c|c|}
\hline $\begin{array}{c}\text { Extraction } \\
\text { method }\end{array}$ & As $^{\mathbf{I I I}}$ & $\mathbf{D M A}^{\mathbf{V}}$ & $\mathbf{M A}^{\mathbf{V}}$ \\
\hline $15 \mathrm{~min} / 80^{\circ} \mathrm{C}$ & $9.7 \pm 0.4$ & $8.9 \pm 0.3$ & $10.1 \pm 0.3$ \\
$30 \mathrm{~min} / 80^{\circ} \mathrm{C}$ & $10.0 \pm 0.1$ & $9.0 \pm 0.1$ & $10.5 \pm 0.3$ \\
$45 \mathrm{~min} / 80^{\circ} \mathrm{C}$ & $10.1 \pm 0.3$ & $8.7 \pm 0.4$ & $10.5 \pm 0.1$ \\
$60 \mathrm{~min} / 80^{\circ} \mathrm{C}$ & $10.1 \pm 0.1$ & $9.0 \pm 0.3$ & $10.4 \pm 0.1$ \\
$30 \mathrm{~min} / 90^{\circ} \mathrm{C}$ & $9.4 \pm 0.1$ & $10.0 \pm 0.2$ & $9.9 \pm 0.1$ \\
$30 \mathrm{~min} / 100^{\circ} \mathrm{C}$ & $9.5 \pm 0.2$ & $10.1 \pm 0.1$ & $10.0 \pm 0.1$ \\
\hline
\end{tabular}

